\title{
INFLUENCE OF WATER TEMPERATURE AND HEAT STRESS ON DRINKING WATER INTAKE IN DAIRY COWS
}

\author{
Ana Valeria González Pereyra ${ }^{1}$, Verónica Maldonado May ${ }^{1}$, Carlos Guillermo Catracchia ${ }^{1}$, \\ María Alejandra Herrero ${ }^{1 *}$, Myriam Celina Flores ${ }^{1}$, and Mariana Mazzini ${ }^{1}$
}

\begin{abstract}
Grazing animals are exposed to heat stress and there should be conditions to facilitate water intake. Three experiments were carried out to determine the relationship between water intake, water temperature, and heat stress for Holstein pastured dairy cows. Experiment 1: Drinking behavior of 13 cows was evaluated (for 3 consecutive days) and four time periods were established according to the temperature humidity index (THI): (H1:05:00 to 10:59 h, H2:11:00 to $16: 59 \mathrm{~h}, \mathrm{H} 3: 17: 00$ to $22: 59 \mathrm{~h}$, and $\mathrm{H} 4: 23: 00$ to $04: 59 \mathrm{~h})$. The highest mean percentage of drinking bouts (53.2\%) was registered in H2 (THI: 74.91 to 83.95). Drinking bout means among time periods were different ( $\mathrm{p}<0.05)$, thus showing that heat stress conditions influence drinking behavior. Experiment 2: Three water troughs were placed in the sun (S) and three under a $2.2 \mathrm{~m}$ high structure covered with shade cloth (MS). Water temperature was registered at 10:00, 13:30, and 17:00 h, twice a week for 6 weeks. Mean water temperatures at 17:00 h were $33.2 \pm 1.6{ }^{\circ} \mathrm{C}$ (S) and $25.3 \pm 1.9^{\circ} \mathrm{C}(\mathrm{MS})$ and showed significant differences $(\mathrm{p}<0.05)$, thus supporting the shade cloth effect. Experiment 3: Five cows were offered water simultaneously at 18 and $31{ }^{\circ} \mathrm{C}$ (T1 and T2), for 10 min, twice a day for $5 \mathrm{~d}$. There were no significant differences among treatments $(\mathrm{p}>0.05)$. Recorded water intake in $\mathrm{T} 1(18 \mathrm{~L})$ was lower than in T2 $(35.9 \mathrm{~L})$, although body heat dissipation was higher $\left(\mathrm{T} 1=672.64 \mathrm{~kJ} \mathrm{~d}^{-1}, \mathrm{~T}_{2}=620.76 \mathrm{~kJ} \mathrm{~d}{ }^{-1}\right)$.
\end{abstract}

Key words: drinking behavior, summer time, THI, grazing dairy farms.

\section{INTRODUCTION}

Dairy cows in Argentina are directly exposed to climatic effects due to the predominant grazing production system predisposing the cows to heat stress situations during spring and summer. Both environmental temperature and relative humidity are factors that jointly determine the environmental effect on the animal's well-being. The combination of both factors determines the temperature and humidity index (THI). At indices above 78, dairy cows are unable to maintain normal body temperatures through thermoregulatory mechanisms (McDowell et al., 1976; Lemerle and Goddard, 1986).

Nutrient metabolism generates heat which must be dissipated in a warm climate by physiological processes

${ }^{1}$ Universidad de Buenos Aires, Facultad de Ciencia Veterinarias, Av. Chorroarín 280 (C1427CWO), Buenos Aires, Argentina. *Corresponding author (aherrero@fvet.uba.ar).

Received: 23 February 2009.

Accepted: 06 July 2009. to maintain thermoneutrality. Dairy cows are in the comfort zone when environmental temperatures are between 5 and $25{ }^{\circ} \mathrm{C}$ (Roenfeldt, 1998). At $26{ }^{\circ} \mathrm{C}$ or more, animal thermoregulatory capacity is surpassed and go into heat stress. Physiological mechanisms start functioning to overcome this state, such as decreasing dry matter consumption reducing metabolic heat generation. According to NRC (2001), with an environmental temperature of $40^{\circ} \mathrm{C}$, consumption of dry matter decreases by $40 \%$.

Drinking water is not only the most important essential nutrient for dairy cattle (Beede, 1991; NRC, 2001), but it also has high specific heat which promotes heat dissipation. There are studies that indicate the direct association between water intake and environmental temperature (Coimbra, 2007; Arias et al., 2008) as well as between water intake and the number of drinking bouts (Matarazzo et al., 2003; Brown-Brandl et al., 2006; Brscic et al., 2007; Coimbra, 2007).

Lactating cows require a great quantity of water which is related to their live weight, dry matter consumption, and production level since it represents $87 \%$ of milk 
volume. When water content in the organism is reduced by $10 \%$, milk and meat production are affected (Herrero, 1998). Therefore, providing water, in quantity and quality, is fundamental in dairy production grazing systems. A characterization of the quality of water used for drinking, as well as washing milking equipment and facilities has been carried out in the dairy basins of Buenos Aires, Argentina. In general terms, the physical and chemical quality of water is acceptable in said region, but differences were found between the Abasto Norte, Abasto Sur, and Abasto Oeste basins (Herrero et al., 2000). It was determined in previous studies that the Oeste dairy basin showed worse underground water quality due to excessive total salts, hardness, chlorides, and sulfates (Herrero and Maldonado May, 2000).

Exposing water troughs to solar radiation increases water temperature in critical seasons and worsens its physical and chemical quality by evaporation causing water intake and milk production to decrease (Challis et al., 1987).

There are studies indicating that a drinking water temperature between 20 and $28{ }^{\circ} \mathrm{C}$ is the most accepted by cattle (Lanham et al., 1986). Other studies indicate that water intake between 7 and $16{ }^{\circ} \mathrm{C}$ reduces tympanic temperature and respiratory frequency in dairy cows (Lanham et al., 1986; Milam et al., 1986; Stermer et al., 1986; Baker et al., 1988), although not the temperature preferred by the animals (Milam et al., 1986; Wilks et al., 1990; Beck et al., 2000). These effects are attributed to the water's refreshing capacity which facilitates heat dissipation and helps to decrease metabolic load (Beck et al., 2000). At the same time, fresh water intake would provoke an increase in dry matter consumption and milk production (Milam et al., 1986; Wilks et al.,
1990). In other studies, Beck et al. (2000) did not find any differences in milk production between cows that consumed water at 17 and $24{ }^{\circ} \mathrm{C}$; however, they indicate an increase in butyric fat production in those animals that consumed fresh water.

The objective of this study was to determine the incidence of water temperature and heat stress on drinking water intake of Holando-Argentino dairy cows during summer months in grazing systems. To that end, three experiments were designed with the following specific objectives: characterize drinking behavior due to the influence of environmental temperature and humidity; evaluate water temperature variations in water troughs directly exposed to solar radiation; and learn about cow preferences for drinking water at different temperatures.

\section{MATERIALS AND METHODS}

\section{Experiment 1}

The experiment was carried out from 05:00 h on 14 February until 05:00 h on 17 February 2003 on a dairy farm located in Arrecifes (3402'49" S, 6008'08' W) Province of Buenos Aires, Argentina, and belonging to the Abasto Norte dairy basin (Figure 1).

Thirteen Holando-Argentino cows were selected with a live weight between 450 and $550 \mathrm{~kg}$, in the last third of the lactation cycle, and milk production between 12 and $16 \mathrm{~L} \mathrm{cow}^{-1} \mathrm{~d}^{-1}$.

Animals grazed daily on a strip of alfalfa (Medicago sativa L.) pasture close to the dairy farm $(100 \mathrm{~m})$ and without supplements. During the experiment, the animals were not in the shade and had free access to a $3 \mathrm{~m}$ linear metal water trough.

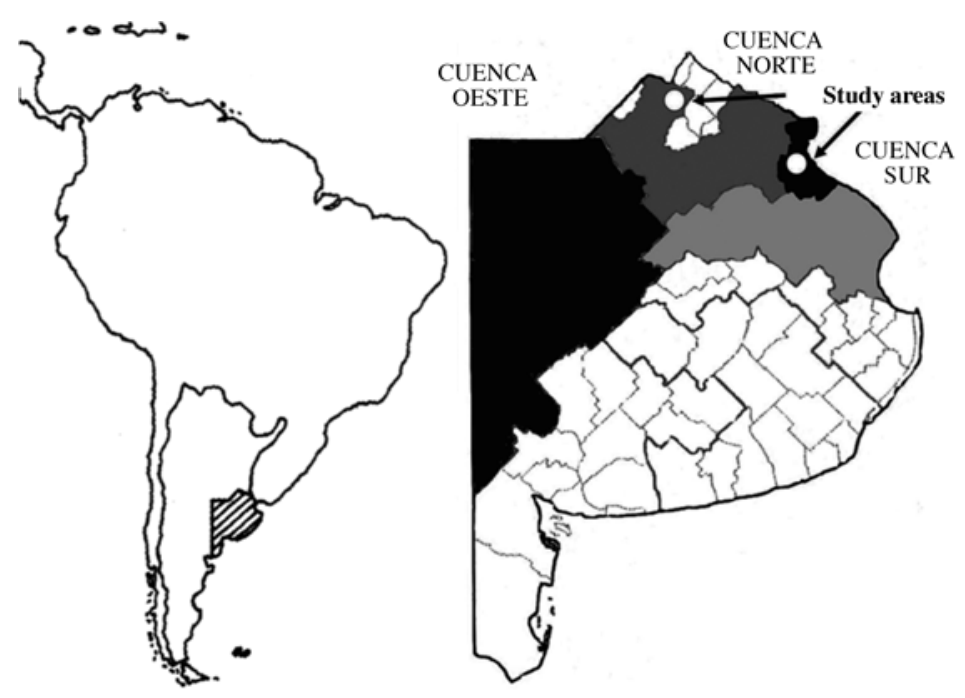

Figure 1. Map of South America showing the location of the Province of Buenos Aires (Argentina), its dairy basins and study areas. 
The floater, which guarantees correct filling of the water trough, was checked to ensure its adequate operation. Each cow was identified with a number on its hindquarters using special animal paint (CELOTEST, Grand Bourg, Argentina).

During the $72 \mathrm{~h}$ of the experiment, environmental temperature and relative humidity were recorded every hour, and providing the temperature and humidity index (THI) determined by the following formula (conversion by Valtorta et al., 1996):

$$
\mathrm{THI}=\left(1.8 \mathrm{~T}_{\mathrm{e}}+32\right)-(0.55-0.55 \mathrm{Rh} / 100)\left(1.8 \mathrm{~T}_{\mathrm{e}}-26\right)
$$

where $\mathrm{T}_{\mathrm{e}}$ : environmental temperature $\left({ }^{\circ} \mathrm{C}\right)$; and $\mathrm{Rh}$ : environmental relative humidity (\%).

Each hour of the day was assigned to one of the THI categories: $<70$ Normal; 70 to 78 Alert; 79 to 82 Danger; and $>82$ Emergency according to the Livestock Weather Safety Index (LCI, 1970). Four time periods were in accordance with climatic data obtained during the experiment.

Six groups of observers working on a 2 -h rotation recorded animal activity during the experiment. Each observer recorded on a chart: all the drinking bouts, defined as those moments when the animal put its snout in the water and actively sucked, animal identification number, and time.

The number of drinking bouts and the mean percentage of cows drinking per hour in each time period were considered to analyze the data. The Friedman test $(\alpha \leq 0.05)$ was applied to evaluate the number of drinking bouts in the distinct time periods, the cows being considered as blocks. The mean percentages of cows that drank according to time periods were analyzed as a completely randomized design $(\alpha \leq 0.05)$.
Subsequently, these mean values were compared with the Tukey test $(\alpha \leq 0.05)$. Spearman's correlation test ( $\alpha$ $\leq 0.05$ ) was carried out to find the relationships between the number of drinking bouts and mean percentage of cows that drank with THI, environmental temperature, and humidity.

Furthermore, within the group of animals, one cow was clearly identified and randomly chosen (focal cow) and the duration of each of its drinking bouts was recorded.

\section{Experiment 2}

The assay was carried out on land belonging to the Faculty of Veterinary Sciences of the Universidad de Buenos Aires (343'ㅇ' S, 58 29'00" W) from 10 January to 17 February 2004. Six circular water troughs with a diameter of $1 \mathrm{~m}$ and height of $0.5 \mathrm{~m}$ were prepared. Three of the water troughs were exposed to the sun (S) and three were placed under a $2.2 \mathrm{~m}$ high, $80 \%$ shade structure (MS) (Valtorta et al., 1996) (Figure 2). Maximum and minimum environmental temperatures were obtained from the Villa Ortúzar Station of the Servicio Meteorológico Nacional located on the assay site. Water temperature $\left({ }^{\circ} \mathrm{C}\right)$ was measured twice a week at three distinct times: 10:00, 13:30, and 17:00 h with alcohol thermometers (Herfor, Buenos Aires, Argentina). Statistical analysis of data was by generalized block design $(\alpha \leq 0.05)$ where treatments were $\mathrm{S}$ and MS and days were considered as randomized blocks with three replicates per treatment. Subsequently, treatment means were compared with the Tukey test $(\alpha$ $\leq 0.05)$.

\section{Experiment 3}

The assay was carried out between 08 January and 13 January 2005 in the same dairy farm as in Experiment

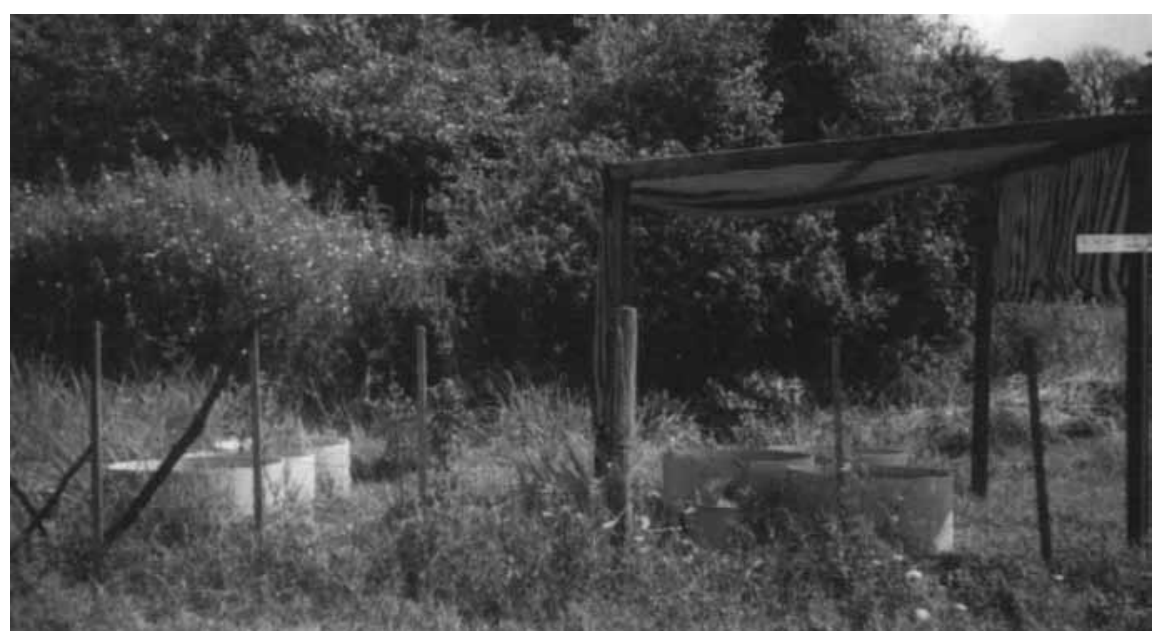

Figure 2. Circular water troughs placed in the sun and under $80 \%$ shade cloth structure. 
1. Five multiparous, pregnant, dry Holando-Argentino cows were selected with live weight between 500 to 550 $\mathrm{kg}$. Each cow entered an individual $30 \mathrm{~m}^{2}$ corral with two water troughs (T1 and T2). The water troughs had the same shape, color, and size $(70 \mathrm{~L})$, were separated $30 \mathrm{~cm}$ one from the other and from the perimeter wire fence. This allowed access to both $\mathrm{T} 1$ and $\mathrm{T} 2$ by the animals according to their preference when they went into the corral. The animals entered for $10 \mathrm{~min}$ at 11:00 and 17:00 h (Lanham et al., 1986; Wilks et al., 1990), these being the only moments they could drink during the day. The cows got used to this routine $48 \mathrm{~h}$ prior to the experiment.

Water was obtained from a perforation close to the corrals, previously analyzed to ensure its chemical quality and related to acceptable values for adult dairy cattle (NRC, 2001). Water trough 1 (T1) contained water at 18 ${ }^{\circ} \mathrm{C}$ which is considered as the mean annual temperature of underground water coming directly from the well. In water trough $2(\mathrm{~T} 2)$, water was at $31{ }^{\circ} \mathrm{C}$, representing the temperature of a water trough exposed to the sun between 11:00 and 17:00 $\mathrm{h}$ during the summer season. The temperature of $\mathrm{T} 2$ was determined according to Experiment 2 results. Water temperatures were recorded with alcohol thermometers (Herfor). Location of the treatments (water troughs) T1 and T2 within the corral were randomly assigned for each day and drinking schedule. Blind observers recorded the duration of each drinking bout (as defined in Experiment 1), trough selected, and after $10 \mathrm{~min}$, they quantified water intake (L) for each selected treatment T1 and/or T2, as well as total intake $\mathrm{T} 1+\mathrm{T} 2$.

Response ratio analysis was calculated (Martin and Bateson, 1993):

$$
\text { Response ratio }=(\mathrm{QT} 1 / \mathrm{QT} 1+\mathrm{QT} 2)
$$

where QT1: quantity of water (L) consumed at water trough 1 (T1); QT2: quantity of water (L) consumed at water trough 2 (T2).

Values were analyzed by the Wilcoxon test (dependent samples) $(\alpha=0.05)$. Taking into account water intake during the 10-min observation and water temperature of each selected treatment, absorbed $\mathrm{kJ}$ were calculated for the animal's water intake by the following equations (Lanham et al., 1986; Milam et al., 1986; Beck et al., 2000):

Body $\mathrm{T}^{\mathrm{o}}\left({ }^{\circ} \mathrm{C}\right)-$ water $\mathrm{T}^{\mathrm{o}}\left({ }^{\circ} \mathrm{C}\right)=$ Cooling value $\left(\mathrm{kcal} \mathrm{L}^{-1}\right)[3]$

where, Cooling value $\left(\mathrm{kcal} \mathrm{L}^{-1}\right) \times 4.18 \mathrm{~kJ} \mathrm{kcal}^{-1} \mathrm{x}$ water intake $(\mathrm{L})=$ Heat absorbed $(\mathrm{kJ})$.

\section{RESULTS AND DISCUSSION}

\section{Experiment 1}

Climatic conditions were similar for the $3 \mathrm{~d}$ with a minimum temperature of $19.5^{\circ} \mathrm{C}$ and a maximum of 33.9 ${ }^{\circ} \mathrm{C}$, historical values for the region for the month of January being 17 and $30{ }^{\circ} \mathrm{C}$, respectively, and a mean of $24{ }^{\circ} \mathrm{C}$. Distribution of the THI categories was the following for the experiment: $8.5 \%$ in "emergency", $4.5 \%$ in "danger", $37 \%$ in "alert", and $13 \%$ in "normal" recorded during the night. In accordance with the climatic data obtained, four time periods were established and identified as $\mathrm{H} 1=$ 05:00 to $10: 59 \mathrm{~h} ; \mathrm{H} 2=11: 00$ to $16: 59 \mathrm{~h} ; \mathrm{H} 3=17: 00$ to 22:59 h; and $\mathrm{H} 4=23: 00$ to $04: 59 \mathrm{~h}$.

Cows drank between 8 and 20 times per day with a mean of $13.56 \pm 6.7$ drinking bouts per cow d $\mathrm{d}^{-1}$, values similar to those reported by Dado and Allen (1994) of 14 \pm 5.63 drinking bouts per cow d $\mathrm{d}^{-1}$, and those recorded by Huzzey et al. (2005) of 13.1 times for lactating dairy cattle. Values observed by Bavera (2009) indicate a frequency of 2 to 7 drinking bouts $\mathrm{d}^{-1}$ for beef cattle, and Cardot et al. (2008) report values of 4.5 to 10.1 times daily for lactating dairy cattle, both in normal winter environmental conditions. Jago et al. (2005) informed a frequency of 5.2 drinking bouts $\mathrm{d}^{-1}$ and Perera et al. (1986) recorded a daily mean of 9.4 drinking bouts for dairy cattle in the summer. Rouda et al. (1994) reported 2 to 3 daily drinking bouts for lactating cattle in the summer, finding that live weight is a bad predictor of water intake behavior. These authors found that responses to drinking bout behavior is highly variable among animals when the environmental temperature exceeds $30{ }^{\circ} \mathrm{C}$, mainly because it would respond to differences in individual behavior.

Table 1 shows the mean values and standard deviations of environmental temperatures and THI according to time periods. Maximum mean percentage of drinking bouts was recorded in $\mathrm{H} 2(53.2 \%)$ and the minimum in $\mathrm{H} 4(2.3 \%)$, corresponding to the time periods ( $\mathrm{H} 2$ and $\mathrm{H} 4)$ in which mean maximum and minimum temperatures and THI occur, respectively. THI was maintained in the "danger" or "emergency" categories during $\mathrm{H} 2$ for $88.8 \%$ of the time, whereas "normal" or "alert" in H4 was maintained $100 \%$

Table 1. Air temperature and temperature humidity index (THI) mean values and standard deviation values according to time periods.

\begin{tabular}{lcc}
\hline Time period & $\begin{array}{c}\text { Environmental } \\
\text { temperature }\left({ }^{\circ} \mathbf{C}\right)\end{array}$ & THI \\
\hline H1 (05:00 to 10:59) & $26.8 \pm 3.87$ & $76.77 \pm 4.44$ \\
H2 (11:00 to 16:59) & $32.1 \pm 2.30$ & $81.23 \pm 1.95$ \\
H3 (17:00 to 22:59) & $27.1 \pm 3.20$ & $76.93 \pm 3.03$ \\
H4 (23:00 to 04:59) & $22.0 \pm 1.31$ & $70.78 \pm 2.43$ \\
\hline
\end{tabular}


of the time without reaching the "emergency" category. These results coincide with those reported by Cowan $e t$ al. (1978) who indicate that frequency and water intake are positively related to the maximum environmental temperature $(\mathrm{p}<0.05)$.

Mean environmental temperature and relative humidity are factors that influence the time that animals spend drinking every day $(\mathrm{p}<0.0007)$ and total water intake ( $\mathrm{p}<0.0006)$ (Coimbra, 2007). In this same study, it was reported that $80 \%$ of drinking bouts occurred between 10:00 and 20:00 h. Water intake during the night represented $2.6 \%$ of the total daily drinking bouts, coinciding with the results obtained in our study and those informed by Andersson et al. (1984). Other authors (Melado, 2003 and Sónio Jr., 2003 as cited by Coimbra, 2007) stated that all drinking bouts for cattle grazing in tropical regions occured in the warmest time periods of the day (10:00 to 15:00 h). Brscic et al. (2007) found that the greatest number of drinking bouts occurred in heat stress situations, and Brown-Brandl et al. (2006) reported an $82 \%$ increase in the number of drinking bouts in situations similar to those shown in our study.

Significant differences were found between the medians of the drinking bouts among time periods when considering cows as blocks (Friedman test, $\mathrm{p}<0.05$ ).

The mean percentage of cows per hour that drank according to the time periods were: $\mathrm{H} 1=32.36 ; \mathrm{H} 2=38.12$; and $\mathrm{H} 3=16.23$ with significant differences among them $(\mathrm{p}<$ 0.05 ). Drinking bouts in $\mathrm{H} 4$ were not considered, not only due to the fact that very few drinking bouts occurred, but that none were recorded during day 3 of the experiment. Furthermore, no day in $\mathrm{H} 4$ recorded THI as a heat stress situation. Comparing paired mean values, only $\mathrm{H} 2$ differed from $\mathrm{H} 3$ $(\mathrm{p}<0.05)$. Mean percentage of cows that drank during the warmest hours (H2) was almost $22 \%$ higher than $\mathrm{H} 3$.

Table 2 shows the correlation between the number of drinking bouts and percentage of cows that made use of the water troughs and THI, environmental temperature, and relative humidity.

In general, as THI values increased, the ratio of cows that drank increased, as well as the number of drinking bouts. However, it was observed that when THI reached

Table 2. Spearman's rank correlation test between number of drinking bouts and percentage of cows that had access to the water trough with temperature humidity index (THI), temperature, and relative humidity.

\begin{tabular}{lccc}
\hline & THI & Temperature & $\begin{array}{c}\text { Relative } \\
\text { humidity }\end{array}$ \\
\hline $\begin{array}{l}\text { Number of } \\
\text { drinking bouts } \\
\text { Cows, } \%\end{array}$ & $0.510^{*}$ & $0.507^{*}$ & $-0.455^{*}$ \\
\hline
\end{tabular}

*p $<0.05$. emergency values $(\mathrm{THI}>82$ ), the number of drinking bouts decreased. Cows got together around the water trough, panting, and not moving from their position during these periods, and a decrease in other voluntary activities, such as eating and walking, was observed. Brown-Brandl et al. (2006) made similar observations in feedlot cattle. This situation could be due to their inability to normally thermoregulate given these levels of THI (McDowell et al., 1976; Lemerle and Goddard, 1986). According to Bavera (2009), when heat is intense, animals spend up to $8 \mathrm{~h}$ (between 09:00 and 10:00 h to 16:00 and 17:00 h) in the vicinity of the waterhole ruminating, resting, and drinking every now and then.

Figure 3 shows drinking behaviors throughout the experiment. Gray areas correspond to THI evolution during the $3 \mathrm{~d}$, white areas the evolution of the percentage of cows that drink every hour, and black bars the number of drinking bouts per hour. It was observed that the highest number of drinking bouts occurs when THI is between 78 and 82 , and animals decrease their drinking behavior when it is greater than 82 (emergency).

A mean of nine drinking bouts $\mathrm{d}^{-1}$ with a mean duration of $33 \mathrm{~s}$ for each one was recorded for the focal cow, its behavior coinciding with the group in relation to THI.

\section{Experiment 2}

During the study period, mean minimum and maximum environmental temperatures were 20.5 and $29.9{ }^{\circ} \mathrm{C}$, respectively, whereas the corresponding absolute minimum and maximum were $17.3{ }^{\circ} \mathrm{C}$ and $37.6{ }^{\circ} \mathrm{C}$. The historical minimum and maximum temperatures in the region for the month of January are 20 and $28{ }^{\circ} \mathrm{C}$ with a mean of $24^{\circ} \mathrm{C}$.

Between 13:30 and 17:00 h, 75\% of the maximum environmental temperatures occurred. Water troughs located in the shade at 17:00 $\mathrm{h}$ had a lower mean temperatures $(p<0.05)$ than those located in the sun, diminishing the effects of environmental temperature on mean water temperature with mean values \pm standard deviations for $\mathrm{MS}=25.3 \pm 1.9^{\circ} \mathrm{C}$ and $\mathrm{S}=33.2 \pm 1.6^{\circ} \mathrm{C}$ (Figure 4). Beede (1993) obtained similar values with 200 water troughs in Florida (USA) in the summer.

Figure 4 shows water temperature distribution of water troughs in the shade and in the sun for all measurement periods. It is observed that water temperatures of troughs under the shade structure were maintained in the temperature range determined as having the best acceptance by cattle, that is, between 20 and $28{ }^{\circ} \mathrm{C}$ in an experiment by Lanham et al. (1986).

Results showed that the $80 \%$ shade structure was effective in decreasing the effects of solar radiation in water temperature. According to the study carried out by Challis et al. (1987), said management also allowed avoiding salt 


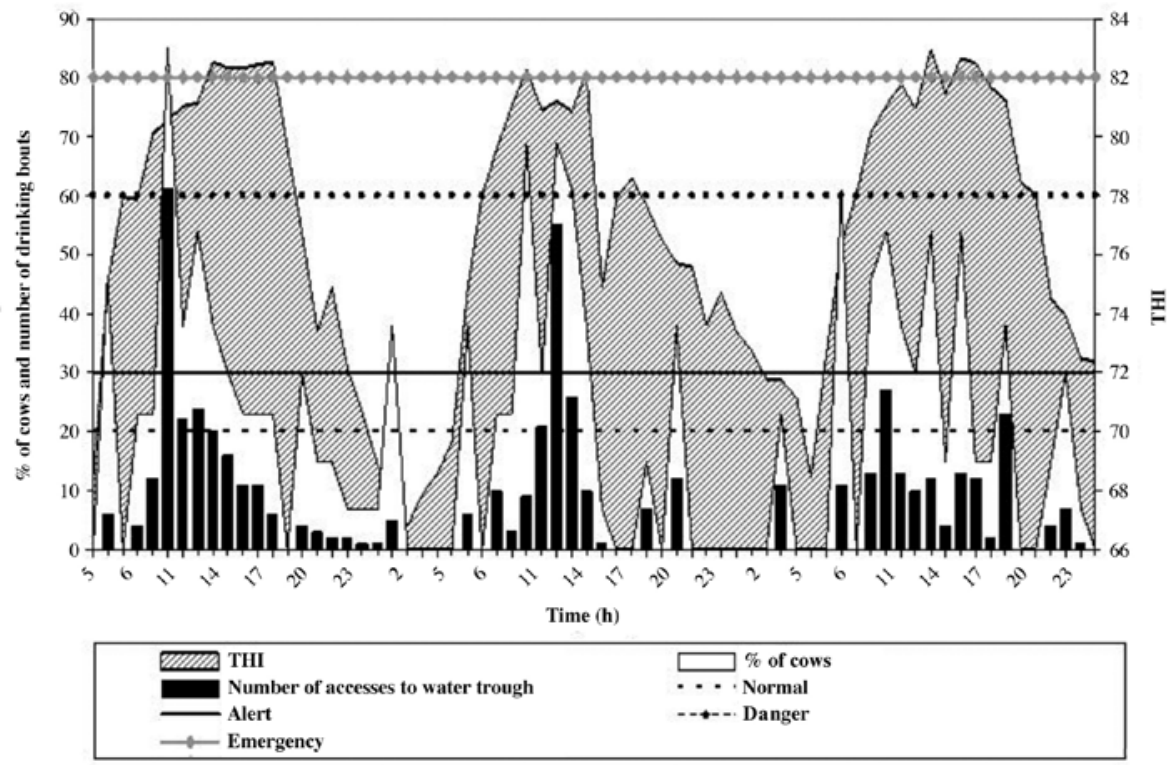

Figure 3. Relationship between number of drinking bouts at the water trough and cow percentage with temperature humidity index (THI).

concentration in drinking water by evaporation, and could thus improve water intake conditions for dairy cattle. The advisability of implementing this practice would be more evident in zones where underground water has a low quality because of excessive salts, such as in the Oeste dairy basin of Buenos Aires (Herrero and Maldonado May, 2000).

\section{Experiment 3}

According to drinking water analysis results, it was determined that it was suitable for animal consumption: sulfates $38 \mathrm{mg} \mathrm{L}^{-1}$; nitrates $61 \mathrm{mg} \mathrm{L}^{-1}$; nitrites $0 \mathrm{mg} \mathrm{L}^{-1}$;

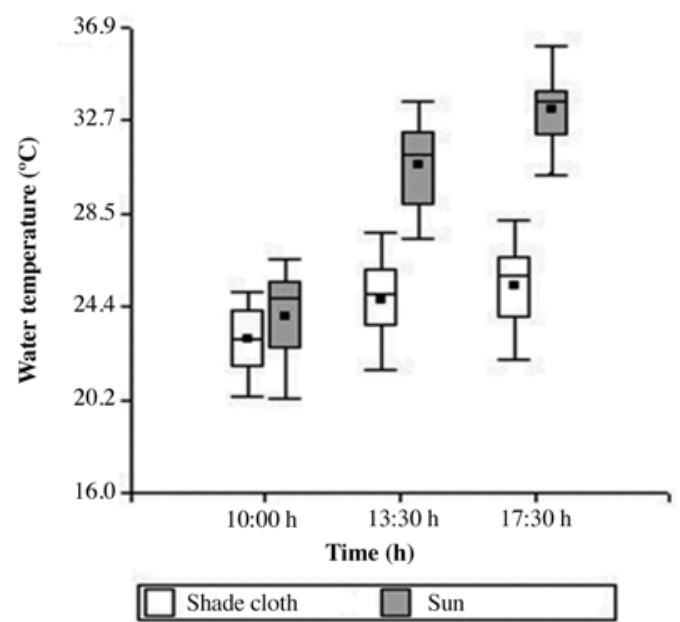

Figure 4. Troughs water temperatures for each treatment (sun and 80\% shade cloth) and time (10:00, 13:30, and 17:00 h). chlorides $50 \mathrm{mg} \mathrm{L}^{-1}$; $\mathrm{pH} 7.51$, electrical conductivity 0.95 mmhos $\mathrm{cm}^{-2}$; and total solids: $792 \mathrm{mg} \mathrm{L}^{-1}$.

No significant differences were observed between response ratios and treatments $(\mathrm{p}>0.05)$ (Table 3$)$. However, a higher water intake was observed at $31{ }^{\circ} \mathrm{C}$.

These results coincide with the work carried out by other authors (Milam et al., 1986; Wilks et al., 1990) who did not find any significant differences in water intake, but noted animal preference for water at a higher temperature. They also coincide with the results obtained by Beck et al. (2000) who observed that $94 \%$ of the animals preferred water at $24{ }^{\circ} \mathrm{C}$, instead of $17^{\circ} \mathrm{C}$. Similar results were obtained in a study carried out with sheep (Savage et al., 2006) where it was observed that animals preferred to drink more water at $30{ }^{\circ} \mathrm{C}$ than at $20{ }^{\circ} \mathrm{C}$ in warm climatic conditions. Osborne et al. (2002) confirmed in experiments carried out in the four annual seasons that dairy cows drank between 3.40 to $5.95 \%$ more water at temperatures between 30 and $33{ }^{\circ} \mathrm{C}$ than between 7 and $15{ }^{\circ} \mathrm{C}(\mathrm{p}<0.05)$. In an extensive study during four summers to evaluate the behavior of 120 animals of different cattle breeds, Lofgreen et al. (1975) recorded that animals not only consumed a lesser quantity of water at $18{ }^{\circ} \mathrm{C}$ compared to $31^{\circ} \mathrm{C}$, but also consumed more feed and improved their weight gains at $18{ }^{\circ} \mathrm{C}$. The interpretation of these authors coincides with the studies by Lanham et al. (1986), Stermer et al. (1986), Milam et al. (1986), Baker et al. (1988), and Wilks et al. (1990) carried out with dairy cows. In these studies, lower fresh water intake (10 to $18{ }^{\circ} \mathrm{C}$ ), higher feed consumption, and higher productivity as compared to water intake at 26 to 
Table 3. Water intake (L) total and for each individual treatment (mean \pm standard deviation) and response ratios for both treatments $\left(\mathrm{T} 1=18^{\circ} \mathrm{C}\right.$ and $\left.\mathrm{T} 2=31^{\circ} \mathrm{C}\right)$.

\begin{tabular}{lccccc}
\hline \multirow{3}{*}{$\begin{array}{c}\text { Animal } \\
\mathbf{n}^{\mathbf{0}}\end{array}$} & $\begin{array}{c}\text { Total } \\
(\mathbf{T 1}+\mathbf{T} 2)\end{array}$ & $\begin{array}{c}\mathbf{T 1} \\
\left(\mathbf{1 8} \mathbf{~}^{\mathbf{C}} \mathbf{C}\right)\end{array}$ & $\begin{array}{c}\mathbf{T 2} \\
\left(\mathbf{3 1} \mathbf{~}^{\mathbf{C}} \mathbf{C}\right)\end{array}$ & $\begin{array}{c}\text { Response ratio } \\
\text { to T1 }\end{array}$ & $\begin{array}{c}\text { Response ratio } \\
\text { to T2 }\end{array}$ \\
\hline 1 & $53.23 \pm 12.48$ & $27.66 \pm 11.92$ & $25.57 \pm 8.29$ & 0.52 & 0.48 \\
2 & $58.82 \pm 22.28$ & $8.12 \pm 2.25$ & $50.70 \pm 20.34$ & 0.14 & 0.86 \\
3 & $70.85 \pm 5.41$ & $19.40 \pm 10.15$ & $43.33 \pm 9.32$ & 0.37 & 0.53 \\
4 & $35.61 \pm 9.81$ & $16.28 \pm 11.61$ & $19.33 \pm 9.04$ & 0.45 & 0.55 \\
5 & $59.8 \pm 14.69$ & $18.80 \pm 16.37$ & $41.00 \pm 19.88$ & 0.31 & 0.69 \\
\hline
\end{tabular}

$32{ }^{\circ} \mathrm{C}$ were observed, as well as evaluating improvements in diverse physiological parameters, justifying that lower fresh water intake allows dissipating enough heat so as to increase feed consumption and milk production. Other studies found similar justifications and also recorded that physiological improvement was maintained for $2 \mathrm{~h}$ when the animals were subjected to heat stress environmental conditions (Purwanto et al., 1996).

Though this study did not evaluate feed consumption or other physiological indicators, it was calculated that with lower water intake at $18{ }^{\circ} \mathrm{C}$, mean absorbed energy was $672.64 \mathrm{~kJ} \mathrm{~d}^{-1}(\mathrm{~T} 1)$, while for water intake at $31{ }^{\circ} \mathrm{C}$, mean absorbed energy was $620.76 \mathrm{~kJ} \mathrm{~d}^{-1}(\mathrm{~T} 2)$. These results suggest that fresh water $\left(18{ }^{\circ} \mathrm{C}\right)$, in spite of not being preferred by the animals, would dissipate heat better.

\section{CONCLUSIONS}

In grazing-based dairy production, such as that found in Argentina, climatic conditions directly influence animal behavior. It was shown that in time periods in which THI reached dangerous levels, the mean percentage of drinking bouts at the water trough was the highest. However, in the presence of extreme THI (> 82), the number of drinking bouts decreases. As a result, it is clear that heat stress conditions influence drinking behavior.

Water in troughs directly exposed to the sun in the summer months showed a temperature increase while water temperatures in troughs in the shade were maintained in the temperature range considered as the most acceptable to the cattle. In the last few years, with the purpose of decreasing heat stress in dairy herds, the use of a shade structure in grazing areas and holding pens has been widespread. Also, our experience shows the convenience of setting it up over water troughs.

Drinking water temperature did not affect intake and it was not possible to demonstrate animal preference for drinking at $18{ }^{\circ} \mathrm{C}$ vs. $31{ }^{\circ} \mathrm{C}$ during heat stress climatic conditions. However, it should be taken into consideration that fresh water dissipates body heat better and will promote greater animal comfort in hot weather.

\section{ACKNOWLEDGEMENTS}

This research was made possible thanks to project funding by the UBACyT Program of the Universidad de Buenos Aires and Fondo para las Américas (Project 20/2000). We also thank the Escuela Agropecuaria $N^{\circ} 1$ of Arrecifes (Buenos Aires) for its disposition in providing facilities and animals for part of these experiments. We acknowledge the following professionals and students who collaborated in the field work: Agronomist Alejandro Cariola, and Veterinarians Agustín A. Orlando, Martín Pol, and Carla Bearzi and students: Marcos Bontá, Omar de Carlos, Mateo Mazziotti, Karina Vasallo, Verónica Gambín, Alejandro Nielsen, Diana Blanco, and Natalia Giménez Asta.

\section{RESUMEN}

Influencia de la temperatura del agua y el estrés calórico sobre el consumo de agua de bebida en vacas lecheras. Los animales en pastoreo están expuestos al estrés calórico, siendo fundamental proveer agua en condiciones que faciliten su consumo. Se desarrollaron tres experimentos para determinar las relaciones entre el consumo del agua de bebida con la temperatura del agua y el estrés calórico, en vacas lecheras en pastoreo. Experimento 1: Se evaluó el comportamiento de abrevado en 13 vacas ( 3 días consecutivos), estableciéndose cuatro franjas horarias según índice de temperatura y humedad (THI): (H1:05:00-10:59 h, H2:11:00-16:59 h, H3:17:0022:59 h y H4:23:00-04:59 h). En H2 (THI: 74,91-83,95) se registró el mayor porcentaje medio de accesos al bebedero $(53,2 \%)$. Las medianas de los eventos "beber" por franjas horarias resultaron diferentes $(\mathrm{p}<0,05)$, demostrándose que las condiciones de estrés calórico influyen sobre el comportamiento de bebida. Experimento 2: Tres bebederos con agua fueron colocados al sol (S) y 
tres bajo estructura de red $80 \%$ sombra (MS), a 2,2 $\mathrm{m}$ de altura, registrándose la temperatura del agua a las 10:00, 13:30 y 17:00 h, dos veces por semana (6 semanas). A las 17:00 h la temperatura media del agua, $33,2 \pm 1,6{ }^{\circ} \mathrm{C}(\mathrm{S})$ y $25,3 \pm 1,9^{\circ} \mathrm{C}$ (MS) presentó diferencias significativas ( $\mathrm{p}<0,05)$, mostrando el efecto de MS. Experimento 3: Se ofreció agua a 18 y $31{ }^{\circ} \mathrm{C}(\mathrm{T} 1$ y T2) durante $10 \mathrm{~min}$ dos veces al día ( $5 \mathrm{~d}$ ) a cinco vacas. No hubo diferencias significativas entre las proporciones de respuesta a los tratamientos $(p>0,05)$. Se registró menor consumo con T1 (18 L) respecto a T2 $(35,9$ L), pero mayor disipación de calor corporal $\left(\mathrm{T} 1=672,64 \mathrm{~kJ} \mathrm{~d}^{-1}, \mathrm{~T} 2=620,76 \mathrm{~kJ} \mathrm{~d}^{-1}\right)$.

Palabras clave: comportamiento de abrevado, época estival, ITH, granjas lecheras pastoriles.

\section{LITERATURE CITED}

Arias, R.A., T.L. Mader, y P.C. Escobar 2008. Factores climáticos que afectan el desempeño productivo del ganado bovino de carne y leche. Arch. Med. Vet. 40:7-22.

Baker, C.C., C.E. Coppock, J.K. Lanham, D.H. Nave, and J.M. LaBore. 1988. Chilled drinking water effect on lactating Holstein cows in summer. J. Dairy Sci. 71:2699-2709.

Bavera, G. 2009. Aguas y aguadas para el ganado. 465 p. $3^{\text {a }}$ ed. Edición Río Cuarto, Río Cuarto, Argentina.

Beck, J., D. Katschke, and H. Steingass. 2000. Heated drinking water for dairy cows. Agrartehnische Forschung 6(4):97-101.

Beede, D. 1991. Dairy nutrition management, mineral and water nutrition. Vet. Clin. N.Am.-Food A. 7:373-390.

Beede, D. 1993. Water nutrition and quality for dairy cattle. Western Large Herd Management Conference, Las Vegas, Nevada, USA. Available at http://www.wdmc. org/1993/ybeede.pdf (accessed September 2009).

Brown-Brandl, T.M., J.A. Nienaber, R.A. Eigenberg, T.L. Mader, J.L. Morrow, and J.W. Dailey. 2006. Comparison of heat tolerance of feedlot heifers of different breeds. Livest. Sci. 105:19-26.

Brscic, M., F. Gottardo, A. Mazzenga, and G. Cozzi. 2007. Behavioral response to different climatic conditions of beef cattle in intensive rearing systems. Available at http://www.dsa.unipd.it/dottorato/produzione $\% 20$ scientifica/20_RAD_Brscic.pdf (accessed September 2009).

Cardot, V., Y. Le Roux, and S. Jurjanz. 2008. Drinking behavior of lactating dairy cows and prediction of their water intake. J. Dairy Sci. 91:2257-2264.

Challis, D.J., J.S. Zeinstra, and M.J. Anderson. 1987. Some effect of water quality on the performance of high yielding cows in an arid climate. Vet. Rec. 120:12-15.
Coimbra, P. 2007. Aspectos extrinsecos do comportamiento de bebida de bovinos em pastoreio. Disertación Mg.Sc. Universidade Federal de Santa Catarina, Brasil. Available at http://www.pos.ufsc. br/arquivos/41000382/diversos/PaulaCoimbra.pdf (accessed September 2009).

Cowan, R.T., D. Shackel, and T.M. Davidson. 1978. Water intakes, milk yield and grazing behaviour of Friesian cows with restricted access to water in a tropical upland environment. Aust. J. Exp. Agric. Anim. Husbandry 18:190-195

Dado, R.G., and M.S. Allen. 1994. Variation in and relationships among feeding, chewing, and drinking variables for lactating dairy cows. J. Dairy Sci. 77:132-144.

Herrero, M.A. 1998. El agua y su importancia en la producción ganadera. Rev. Georgica 6:67-87. Universidad de Zaragoza, Escuela Politécnica de Huesca, España.

Herrero, M.A., y V. Maldonado May. 2000. Calidad de agua, un desafío para la lechería. Industria y Química 339:18-23.

Herrero, M.A., G.M. Sardi, V. Maldonado May, M. Flores, A.A. Orlando, y L.I. Carbó. 2000. Distribución de la calidad del agua subterránea en sistemas de producción agropecuarios bonaerenses. 1. Calidad físico química y condiciones de utilización del agua. Rev. Arg. Prod. Anim. (AAPA) 20(3-4):229-237.

Huzzey, J.M., M.A. G. von Keyserlingk, and D.M. Weary. 2005. Changes in feeding, drinking, and standing behavior of dairy cows during the transition period. J. Dairy Sci. 88:2454-2461.

Jago, J.G., J.R. Roche, E.S. Kolver, and M.W. Woolford. 2005. The drinking behaviour of dairy cows in late lactation. Proc. N.Z. Soc. Anim. Prod. 65:209-214.

Lanham, J.K., C.E. Coppock, K.Z. Milam, J.M. LaBore, and D.H. Nave, 1986. Effect of drinking water temperature on physiological responses of lactating Holstein cows in summer. J. Dairy Sci. 69:1004-1012.

LCI. 1970. Patterns of transit losses. Livestock Conservation Inc., Omaha, Nebraska, USA.

Lemerle, C., and M.E. Goddard. 1986. Assessment of heat stress in dairy cattle in Papua New Guinea. Trop. Anim. Health Prod. 18:232-242.

Lofgreen, G.P., R.L. Givens, S.R. Morrison, and T.E. Bond. 1975. Effect of drinking water temperature on beef cattle performance. J. Anim. Sci. 40:223-229.

Martin, P., and P. Bateson. 1993. Measuring behaviour: An introduction guide. $2^{\text {nd }}$ ed. 222 p. Ed. Cambridge University Press, Cambridge, UK. 
Matarazzo, S.V., M. Perissinoto, J. Oliveira da Silva M., D. Jorge de Moura, and K. Botigeli Sevegnani. 2003. Water intake and behaviour of dairy cows in response to environmental conditions. p. 213-217. In Fifth International Dairy Housing Proceedings, Fort Worth, Texas. 29-31 January. American Society of Agricultural and Biological Engineers, St. Joseph, Michigan, USA.

McDowell, R.E., N.W. Hooven, and J.K. Camoens. 1976. Effects of climate on performance of Holsteins in first lactation. J. Dairy Sci. 59:965-973.

Milam, K.Z., C.E. Coppock, J.W. West, J.K. Laham, D.H. Nave, and J.M.LaBore. 1986. Effect of drinking water on temperature on production responses in lactating Holstein cows in summer. J. Dairy Sci. 69:1013-1019. NRC. 2001. Nutrient requirements of dairy cattle. $7^{\text {th }}$ revised ed. p. 178-183. National Research Council, Natl. Acad. Press, Washington D.C., USA.

Osborne, V.R., R.R. Hacker, and B.W. McBride. 2002. Effects of heated drinking water on the production responses of lactating Holstein and Jersey cows. Can. J. Anim. Sci. 82: 267-273.

Perera, K.S., F.C. Gwazdauskas, R.E. Pearson, and T.B. Brumback Jr. 1986. Effect of season and stage of lactation on performance of Holsteins. J. Dairy Sci. 69:228-236.

Purwanto, B.P., M. Harada, and S. Shamamoto. 1996. Effect of drinking-water temperature on heat balance and thermoregulatory responses in dairy heifers. Austr. J. Agric. Res. 47:505-512.
Roenfeldt, S. 1998. You can't afford to ignore heat stress. Dairy Manage. 35(5):6-12.

Rouda, R.R., D.M. Anderson, J.D. Wallacce, and L.W. Murray. 1994. Free-ranging cattle water consumption in southcentral New Mexico. Appl. Anim. Behav. Sci. 39:29-38.

Savage, D., J. Nohlan, I. Godwin, A. Aoetpah, T. Nguyen, N. Baillie, et al. 2006. Importance of drinking water temperature for managing heat stress in sheep. Available at http://www.agric.wa.gov.au/objtwr/ imported_assets/content/aap/heat_stress_savage.pdf (accessed September 2009).

Stermer, R.A., C.F. Brasington, C.E. Coppock, J.K. Lanham, and K.Z. Milam. 1986. Effect of drinking water temperature on heat stress of dairy cows. J. Dairy Sci. 69:546-551.

Valtorta S.E., M.R. Gallardo, H.C. Castro, and M.E. Castelli. 1996. Artificial shade and supplementation effects on grazing dairy cows in Argentina. Trans. ASAE 39:233-236.

Wilks, D.L., C.E. Coppock, J.K. Lanham, K.N. Brooks, C.C. Baker, W.L. Bryson, et al. 1990. Responses of lactating Holstein cows to chilled drinking water in high ambient temperatures. J. Dairy Sci. 73:10911099. 